\title{
Comparative Analysis between the Value of Biological Assets and Agricultural Products, Using Market Approaches and Income Approaches in the Post PSAK 69 Agriculture at Palm Oil Plantation
}

\author{
Hery Sanukri Munte1, Khaira Amalia Fachrudin², Rina Br Bukit² \\ ${ }^{1}$ Property Management and Valuation Master Programme, Universitas Sumatera Utara, Jalan Almamater Kampus USU, Medan, \\ Indonesia \\ ${ }^{2}$ Faculty of Economic and Business, Universitas Sumatera Utara, Jalan TM Hanafiah Kampus USU, Medan, Indonesia \\ Email: sanukrimunte@yahoo.co.id, khaira@usu.ac.id, rina.bukit@usu.ac.id
}

How to cite this paper: Munte, H.S., Fachrudin, K.A. and Bukit, R.B. (2019) Comparative Analysis between the Value of Biological Assets and Agricultural Products, Using Market Approaches and Income Approaches in the Post PSAK 69 Agriculture at Palm Oil Plantation. Open Journal of Business and Management, 7, 1144-1152.

https://doi.org/10.4236/ojbm.2019.73079

Received: May 10, 2019

Accepted: May 21, 2019

Published: May 24, 2019

Copyright $\odot 2019$ by author(s) and Scientific Research Publishing Inc. This work is licensed under the Creative Commons Attribution International License (CC BY 4.0).

http://creativecommons.org/licenses/by/4.0/

\begin{abstract}
Property of palm oil plantation is income producing property in which oil palm is the most important commodity which has the biggest contribution to the creation of values. Palm oil plants are biological assets which experience growth transformation and need a long period from seedlings to productive plants. Therefore, it is necessary to have the measurement which can indicate the value of the property appropriately according to its contribution. Cost model is usually used in presenting financial statement which is referred to PSAK 16 on fixed asset that does not reflect the real quality of asset since it is only recorded its cost. PSAK 69 agriculture applies fair value to respond to some uniqueness of the agricultural characteristics of oil palm. The objective of the research was to analyze the difference between the value of biological assets and agricultural products by using market and income approach. The research used quantitative case study approach which was aim to assess oil palm plants at private estate in Kabupaten Langkat. Direct comparison method was used for market approach while Discounted Cash Flow (DCF) was used for income approach. The data were gathered through internal report analysis and semi-structured interviews. The result of the research showed that the value of biological assets in pre-PSAK 69 was IDR.121,140,000,000 while in the post-PSAK 69 the recorded value consisted of two parts: fair value of bearer plants and fair value of agricultural products. Through market approach, it was found that fair value of bearer plants was IDR.118,083,410,741
\end{abstract}


and fair value of agricultural products was IDR.3,056,589,259. Through income approach, it was found that fair value of bearer plants was IDR.110,354,000,000 and fair value of agricultural products was IDR.10,786,000,000. The conclusion was that the difference in fair value of agricultural products, assessed by using market approach and by using income approach, was $252.9 \%$.

\section{Keywords}

Biological Assets, Fair Value, Agricultural Product, PSAK 69

\section{Introduction}

Biological asset is unique because it undergoes transformation of growth which takes a long time, from seeds to bearer plants. It is unique since it always grows even though it has produced. It has changed since it grows; its asset degrades, and produces. This condition will influence the changes in assets quantitatively and qualitatively. Biological asset can provide new agricultural products as the addition of equal biological assets. By these biological changes, measurement which is able to assess the assets appropriately is adjusted based on the contribution and the agreement to get profits more economically for the entity [1]. With the globalization financial standard, big multinational companies gradually present their financial statements from recording, measuring, presenting, and disclosing by referring to PSAK (Financial Accounting Standard Statement). The concept of historical cost (cost or value of book model) is usually used to measure the asset value of agricultural company plants in Indonesia. This is because the SAK (financial accounting standard) in Indonesia still does not regulate the measurement of asset value of plants so that PSAK 16 (fixed asset) is still used [2]. PSAK 69 Agriculture is used to respond to the 3 (three) kinds of uniqueness of agricultural characteristics-the increase in agricultural assets through the process of growth; earning is related to the growth of assets, and financial statement of agricultural companies still use cost model in which asset recorded value does not reflect the real quality since it is recorded in the amount of the cost spent.

For the purpose of financial statement (IAS 41/PSAK 69), plant assets are separated into two groups: bearer plants and agricultural products [3]. Therefore, the title of the research was "Comparative Analysis between the Value of Biological Assets and Agricultural Products, Using Market and Income Approaches in the post PSAK 69 Agriculture in Palm Oil Plantations". Its subjective was to analyze the value of biological assets of agricultural products by using two research methods.

The scope of the research was limited in the formula of the problems: how about the difference in fair value of biological assets from agricultural products by using valuation approach. 


\section{Theory}

Valuation is the process of certain work which gives estimation and idea on an economic value or valuation in certain time which is in accordance with SPI and prevailing regulations (KEPI-SPI, 2018: 3.7) [4]. Valuation approach constitutes the basis for the process of valuation equipped by the valuation method of each approach. The selection of appropriate valuation approach highly depends on consideration like the determined purpose and the basis for values, the availability of input information and data of valuation and the relevant methods or techniques applied by marketers [4].

Market approach is an approach used to get the value of a certain property by comparing it with the other properties of the same kind which value has been known [4]. Comparison approach of market data can be used for all kinds of property. Especially for the market data of TBS (Fresh Fruit), price is influenced by oil content and core oil content determined by the age of a plant. Since market data such as TBS which is not ripe enough, it is necessary to make an adjustment to the factor of oil content which is explained as the adjustment material in establishing values. Based on the result of the research done by AfshinKeshvadi, Johar Bin Endan, Haniff Harun, Desa Ahmad, and Farah Saleena [5] with the title, The Reflection of Moisture Content on Palm Oil Development During the Ripening Process of Fresh Fruits, it can be concluded that fruit which has had palm oil content is the fresh fruits which will be harvested in the period of 1 (one) month and 2 (two) months with the oil content composition of $45.6 \%$ and $34.0 \%$ respectively.

Income approach has the indication of value by changing the future cash flow to the current value. This approach considers earnings yielded by assets during the period of its benefit and calculates value through the process of capitalization. In general, Discounted Cash Flow (DCF) is used to calculate the fair value of biological assets and agricultural products in which an included cash flow is the projection of earnings the total fruit being produced (during the projection of 4 months) [4].

Fair value is the estimation of price which will be received from the sale of assets or paid to transfer liability in regular transaction among consumers on the date of valuation (SPI 102-3 19, 2018) [4]. Definition of the Fair Values is in accordance with the definition found in PSAK 68. In the SPI (Indonesian Valuation Standard), definition of fair value for financial statement is in accordance with the prerequisites of the prevailing accounting standard (SPI 201-Valuation for Financial Statement) (SPI 102-3.19.1/2018). Fair value is the term used in accounting which is different from market value even though both of them have the same size in acertain condition. These two values have different definitions. Fair value has wider concept than market value. Even though in many cases fair price between two parties will get the same result in a market; in a certain case, valuation with fair value will consider various ignored things in valuation using market value [4]. 
Valuation of biological assets and agricultural products for financial statement which is regulated in IAS 41 or PSAK 69, especially for agricultural products, is measured in the initial and the final recognition of each reporting period as Fair Value mines the cost for selling during the harvest time.

In palm oil plants, the agricultural product is fresh fruits which can be harvested when the fruit has been in the period when the amount and harvest time have been known.

The hierarchy of Fair Value gives high priority to the price of the fruit which is directly picked up from the identical liability market (input level 1) or quotation price (without adjustment) in active market for assets or identical liability (input level 1). Then, the input can be observed from market/market data, either directly or indirectly (input level 2) in the lowest priority for unobserved input from the market (input level 3) which is usually related to specific property or property with limited market (Figure 1) [6].

Discount rate, the cost of capital indicates the minimum rate of return required by the various sources of financing of a company or theminimum return required to attract investment (Borsatto, Correia \& Gimenes) [7]. Second Damodaran (2007, p. 19), "indiscounted cash flow valuations, discount rates should reflect the degree of risk of cash flows" [8].

Discount rate can be defined as the rate used to calculate the present value (PV) of future cash flows, that is, the expected value of cash flows at present value (Ross, Westerfield \& Jaffe; Copeland, Koller \& Murrin; Damodaran) [9], Póvoa [10] indicates discount rate as one of the most important estimates for calculation of the present value of cash flows. Discount rate is calculated using the method of calculating the return of loan capital and own capital (Band of Investment Method/BOIM).

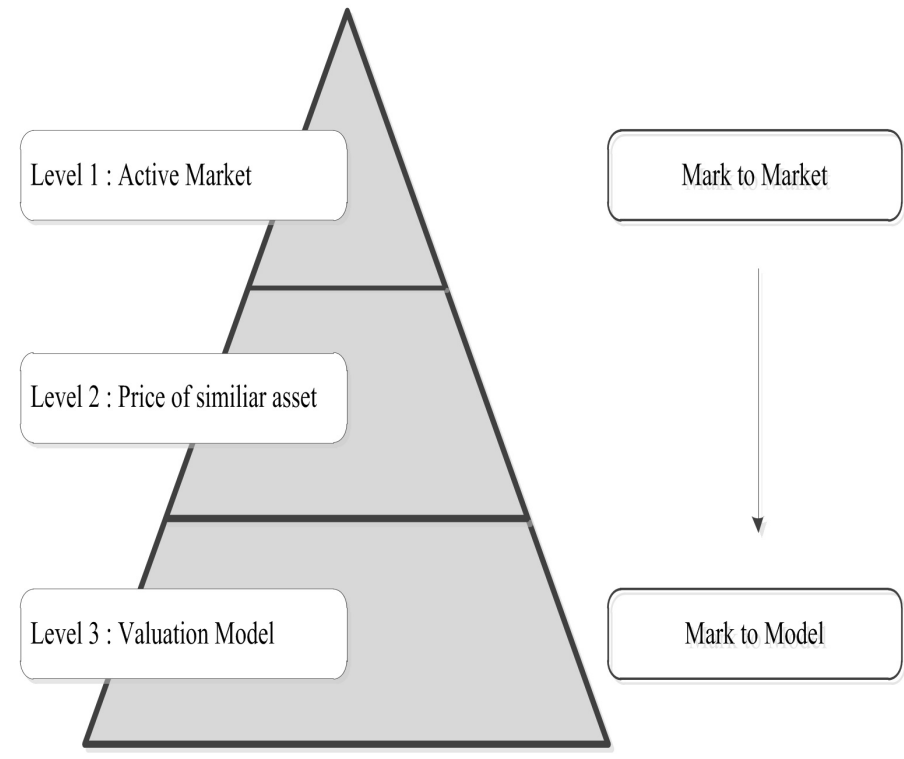

Figure 1. Hierarchy of measuring fair value, Source: Prepared by authors based on IFRS 13 . 


\section{Conceptual Framework (Figure 2)}

The value of plantation property is the addition of the value of land, the value of plants, and the value of non-plant assets. The value of plants is the deviation of property value of plantation minus the value of non-plant assets [11]. In accordance with PSAK 16 on fixed assets prior to PSAK 69, the value of bearer plants (plant stand) is the value of plants minus the value of agricultural products. Bearer plants are live plants which;

1) are used in production or in the preparation of agricultural products;

2) are expected to produce products in more than one period; and

3) have the rare possibility to be sold as agricultural products except for the sale of incidental scrap.

Agricultural products are the products which have been harvested from biological assets [3]. The value of agricultural products or fresh fruit, is calculated by using two approaches: market approach with direct comparison method and income approach with discounted cash flow method.

\section{Research Method}

The research used quantitative method with observational descriptive explanatory design. Observational design is focused on systematic observation and recording on ay phenomena in the research subjects. The data were gathered from December 1, 2018 until February 1, 2019. The time of valuation (cut-off date) on December 31, 2018 which is in accordance with the date of financial statement at the oil palm plantation private state located at DesaSeiMusam, KabupatenLangkat, Provinsi Sumatera Utara.

The research population was the land area of 1924.28 hectares, and 96,214 hectares of them (5\%) were used as the samples. The size or measurement of the

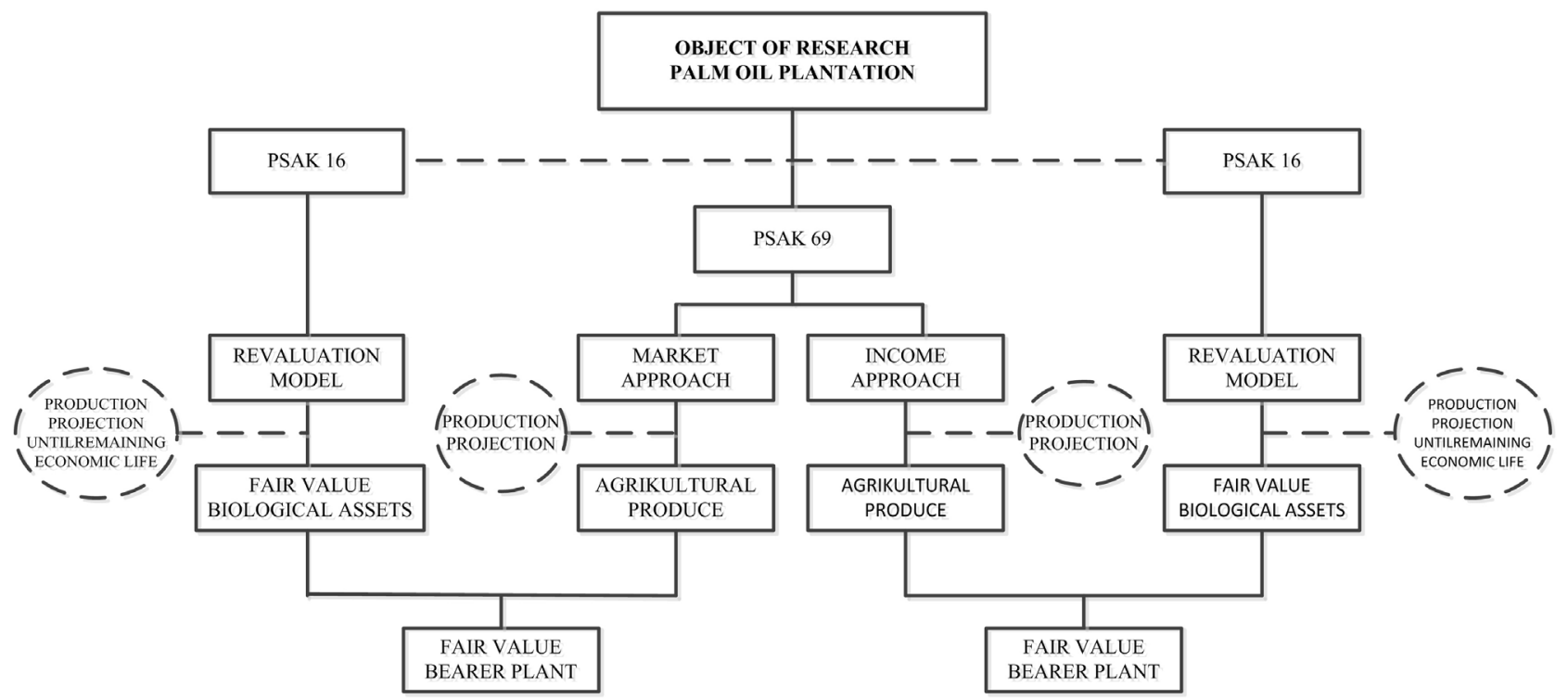

Figure 2. Conceptual framework. 
sample highly depends on the level of carefulness or errors wanted by a researcher. However, in the case of the maximum level of error, it is 5\% (0.05) in the social research. The higher the level of error is, the fewer the number of samples. But it is necessary to note that the more the number of samples (getting close to population), the less possibility of generalized errors and vice versa, and the fewer the number of samples is (being far from population), the more possibility of generalized errors. The research data were continuous data: oil palm plants which had produced TBS (fresh fruit) which was put in order based on planting years.

\section{Result and Discussion}

Before PSAK 69 on agricultural products was applied, the entity would record the fair value of IDR.121,140,000,000 with discount rate $12.78 \%$ in the financial statement on December 31, 2018 into its fixed assets (Table 1).

Table 1. Discounted cash flow analysis using PSAK 16 Revaluation Models.

\begin{tabular}{|c|c|c|c|c|c|}
\hline & Year-1 & Year-2 & Year-3 & Year-4 & Year-5 \\
\hline \multicolumn{6}{|l|}{ Revenue } \\
\hline Estate Output (FFB ton) & 41114.47 & 40149.33 & 39259.81 & 38543.46 & 37781.16 \\
\hline $\begin{array}{l}\text { Unit Price FFB } \\
\text { (IDR.000/ton) }\end{array}$ & 1528.45 & 1598.77 & 1672.33 & 1749.27 & 1829.75 \\
\hline Total Revenue & 62841.569 & 64189.730 & 65655.377 & 67422.950 & 69130.105 \\
\hline \multicolumn{6}{|l|}{ Expenses } \\
\hline $\begin{array}{c}\text { Harvesting \& } \\
\text { Transportation Cost }\end{array}$ & 10327.723 & 10555.193 & 10802.244 & 11099.272 & 11386.678 \\
\hline Upkeeping Cost & 9055.666 & 9255.119 & 9471.741 & 9732.184 & 9984.191 \\
\hline Overhead Cost & 7190.576 & 7348.949 & 7520.956 & 7727.759 & 7927.863 \\
\hline Total Operating Expenses & 26573.964 & 27159.261 & 27794.941 & 28559.216 & 29298.732 \\
\hline Net Operating Income & 36267.605 & 37030.469 & 37860.435 & 38863.734 & 39831.373 \\
\hline Discount Rate & $12.78 \%$ & $12.78 \%$ & $12.78 \%$ & $12.78 \%$ & $12.78 \%$ \\
\hline Discount Factor & 0.887 & 0.786 & 0.697 & 0.618 & 0.548 \\
\hline Present Value & 32158.843 & 29115.369 & 26395.520 & 24025.403 & 21833.983 \\
\hline $\begin{array}{l}\text { Gross Value of Plantation } \\
\text { (IDR.000) }\end{array}$ & 185940.000 & & & & \\
\hline Land & 45200.000 & & & & \\
\hline Builidngs & 16000.000 & & & & \\
\hline $\mathrm{M} \& \mathrm{E}$ & 3000.000 & & & & \\
\hline Inventories & 600.000 & & & & \\
\hline Fair Value & & & & & \\
\hline $\begin{array}{l}\text { Biological Assets } \\
\quad \text { (IDR.000) }\end{array}$ & 121140.000 & & & & \\
\hline
\end{tabular}

Source: Prepared by the author based on data analysis. 
In the post PSAK 69, by using market approach, the entity would also record the Fair Value of Biological assets of IDR.118,083,410,41 into its fixed assets, and the Fair Value of Agricultural products assets of IDR.3,056,589,259 into its current assets (Table 2).

Meanwhile, when income approach was used, the entity would record the Fair Value of Biological Assets of IDR.110,354,000,000 into its fixed assets, and the Fair Value of Agricultural product assets of IDR.10,786,000,000 into its current assets (Table 3 ).

Table 2. Market approach analysis using PSAK 69 Revaluation Models.

\begin{tabular}{ccc}
\hline & Month-1 & Month-2 \\
Estate Output (FFB; kg) & 3136614.00 & 2831651.00 \\
Adjusment Factor & $45.62 \%$ & $33.98 \%$ \\
Unit Price FFB (IDR./kg) & 1.528 & 1.528 \\
Harvesting \& Transportation (IDR./kg) & 251.19 & 251.19 \\
Agriculture Produce & 1827763.203 & 1228826.056 \\
Total Agriculture Produce (IDR) & 3056589.259 \\
Biological Assets (IDR) & \multicolumn{2}{c}{121140000.000} \\
Bearer Plant (IDR) & \multicolumn{2}{c}{118083410.741} \\
\hline
\end{tabular}

Source: Prepared by the author based on data analysis.

Table 3. Income analysis using PSAK 69 Revaluation Models

\begin{tabular}{|c|c|c|c|c|}
\hline & Month-1 & Month-2 & Month-3 & Month-4 \\
\hline \multicolumn{5}{|c|}{ Revenue } \\
\hline Estate Output (FFB; kg) & 3136614.00 & 2831651.00 & 3237602.00 & 3354148.00 \\
\hline Unit Price FFB (IDR./kg) & 1528 & 1528 & 1528 & 1528 \\
\hline Total Revenue & 4794169.595 & 4328047738 & 4948525.088 & 5126660.265 \\
\hline \multicolumn{5}{|c|}{ Expenses } \\
\hline Harvesting \& Transportation Cost & 787899.718 & 711294.735 & 813267.333 & 842543.030 \\
\hline Upkeeping Cost & 690854.772 & 623685.161 & 713097.880 & 738767.714 \\
\hline Overhead Cost & 548567.445 & 495231.977 & 566229.398 & 586612.314 \\
\hline Total Operating Expenses & 2027321.935 & 1830211.873 & 2092594.611 & 2167923.058 \\
\hline Net Operating Income & 2766847.660 & 2497835.865 & 2.855 .930 .477 & 2.958.737.207 \\
\hline Discount Rate & $12.78 \%$ & $12.78 \%$ & $12.78 \%$ & $12.78 \%$ \\
\hline Discount Factor & 0.989 & 0.979 & 0.969 & 0.959 \\
\hline Agriculture Produce & 2737699.237 & 2445484.255 & 2766617.324 & 2836013.808 \\
\hline Total Agriculture Produce (IDR) & \multicolumn{2}{|c|}{10785814.625} & & \\
\hline Biological Assets (IDR) & \multicolumn{2}{|c|}{121140000.000} & & \\
\hline Bearer Plant (IDR) & \multicolumn{2}{|c|}{110354000.000} & & \\
\hline
\end{tabular}

Source: Prepared by the author based on data analysis. 
Based on the result above, it was concluded that the fixed assets of the company's entity, when market approach was used, was IDR.118,083,410,741 and the fixed value of the company's entity, when income approach was used, was IDR.110,354,000,000. In this case, the fixed assets were oil palm bearer plants which will decrease until their economic age comes to end. By assuming using the same shrinking method, the heavier load of shrinking in the fixed assets, using market approach, would be obtained because the assets in market approach were bigger. The heavier load on the shrinking minus earnings would influence payable profit which was used to calculate the payable corporate PPh (income tax). The heavier the shrinking load was, the less profit which became the basic tax calculation.

\section{Conclusion and Suggestion}

The measurement of fair value of biological assets in the post PSAK 69 is divided into two fair values: bearer plant fair value and agricultural product fair value, using revaluation method, market approach, and income approach. In market approach, fair value of biological assets and agricultural products used total projection of fresh fruit for the period of 2 months before harvest, while in income approach, the value of biological assets and agricultural products used total projection of fresh fruit for the period of 4 months prior to harvest.

The difference in fair value of agricultural products occurs when it is valued by using market approach, compared with using income approach of $252.9 \%$. The fair value of agricultural product by using market approach is lower than using income approach. Based on the result of assessment using the above method, there was significant difference from the result of assessment using agricultural products (supply). The difference can be seen from various viewpoints. Market approach which only uses the projection of fruit in 2 months is considered more realistic by some people since fresh fruit will immediately be sold so that there will be few supplies. Income approach is considered by some people as more relevant since it describes current condition of supply: fresh fruit exists on the plants and will be harvested on time.

By using market approach, fair value of agricultural products was smaller than that of using income approach so that it would meet the principle of conservatism in accounting-the stress in choosing the lowest/smallest alternatives. By market approach, the fair value of agricultural products was smaller than that by income approach.

\section{Conflicts of Interest}

The authors declare no conflicts of interest regarding the publication of this paper.

\section{References}

[1] Meilansari, A.Y. and Maslichah, M.C.M. (2019) Evaluation of Application PSAK 69 Agriculture on Biological Assets. Jurnal Ilmiah Riset Manajemen, 8, 2. 
[2] Dvorakova, D. (2006) Application of Fair Value Measurement Model in IAS 41-Relation between Fair Value Measurement Model and Income Statement Structure. University of Economic, Prague.

[3] Indonesian Accounting Association (2018) Financial Accounting Standards. PSAK, Salemba Empat Jakarta, Jakarta.

[4] KEPI \& SPI (2018) Kode Etik Penilai Indonesia dan Standar Penilaian Indonesia. Jakarta.

[5] Afshin, K., Endan, J.B., Harun, H., Ahmad, D. and Salena, F. (2012) The Reflection of Moisture Content on Palm Oil Development during the Ripening Process of Fresh Fruits. https://www.wflpublisher.com/

[6] International Financial Reporting Standards IFRS-13 (2010) Fair Value Measurement.

[7] Borsatto Jr., J.L., Correia, E.F. and Gimenes, R.M.T. (2015) Avaliação de empresas pelo método do fluxo de caixa descontado: O casode uma indústria de ração animal e soluções em homeopatia. Contabilidade Vista \& Revista, 26, 90-113.

[8] Damodaran, A. (2007) Avaliação de empresas. Pearson Prentice Hall, São Paulo, $464 \mathrm{p}$.

[9] Ross, S.A., Westerfield, R.W. and Jaffe, J.F. (2002) Administração financeira. Atlas, São Paulo, 776 p.

[10] Póvoa, A. (2007) Valuation: Como precificar ações. 2nd Edition, Globo, São Paulo, $373 \mathrm{p}$.

[11] Yusuf, H. (2018) Teknik Penilaian Properti Perkebunan, PKP2A Pendidikan Khusus Penilai Properti Agri MAPPI. 